\title{
Surfaces
}

\section{Transforming Differences into "Normality". German Unification and the Crisis of the Humanities}

\section{Karlheinz Barck}

Volume 6, 1996

LES ÉCONOMIES DISCURSIVES DU SAVOIR ET DE LA CULTURE DANS LE SILLAGE DE L'OEUVRE DE BILL READINGS

THE DISCURSIVE ECONOMIES OF KNOWLEDGE AND CULTURE, WITH CONSTANT REFERENCE TO THE WORK OF BILL READINGS

URI : https://id.erudit.org/iderudit/1064852ar

DOI : https://doi.org/10.7202/1064852ar

Aller au sommaire du numéro

Éditeur(s)

Les Presses de l’Université de Montréal

ISSN

1188-2492 (imprimé)

1200-5320 (numérique)

Découvrir la revue

Citer cet article

Barck, K. (1996). Transforming Differences into "Normality". German

Unification and the Crisis of the Humanities. Surfaces, 6.

https://doi.org/10.7202/1064852ar
Résumé de l'article

Ce texte, écrit au printemps 1992, décrit certains effets de l'unification de l'Allemagne laquelle peut être appelée unification de deux systèmes de pensée différents. Cet essai examine comment, dans les sciences humaines, la haine de la politique mène à une "dépolitisation " des institutions savantes de la République Démocratique d’Allemagne : elle les «normalise » en les accordant aux standards de l'Ouest, tout en les menant vers des frictions et des conflits qui vont à l'encontre de la "normalisation », supposée universelle, des "standards de l'Ouest". 


\section{Transforming Differences into "Normality" \\ German Unification and \\ the Crisis of the Humanities}

Karlheinz Barck

Forschungsschwerpunkt Litteraturwissenschaft

Berlin

barck@zfl.ag-berlin.mpg.de

Surfaces Vol. VI. 207 (v.1.0A - 22/12/1996) - ISSN:

1188-2492

Copyright for texts published in Surfaces remains the property of authors. However, any further publication should be accompanied by an acknowledgement of Surfaces as the place of initial publication.

\section{ABSTRACT}

The text, written in spring, 1992, describes certain effects of the German unification process on what has been called the unification of two different scholarly systems. This essay examines how, in the humanities, the hasty political drive to depoliticize the scholarly institutions of the former German Democratic Republic and normalize them according to Western standards, led to frictions and clashes that run counter to normalization as well as to the supposed universality of Western standards.

\section{RÉSUMÉ}

Ce texte, écrit au printemps 1992, décrit certains effets de l'unification de l'Allemagne 
laquelle peut être appelée unification de deux systèmes de pensée différents. Cet essai examine comment, dans les sciences humaines, la haine de la politique mène à une dépolitisation des institutions savantes de la République Démocratique d'Allemagne: elle les normalise en les accordant aux standards de l'Ouest, tout en les menant vers des frictions et des conflits qui vont à l'encontre de la normalisation, supposée universelle, des standards de l'Ouest .

\section{Avant-propos}

J'envoie ce texte à la revue électronique Surfaces pour son numéro spécial à la mémoire de notre ami Bill Readings parce qu'il porte des traces de l'intérêt de Bill pour les questions qui y sont abordées, trop rapidement, il est vrai, et en fonction des circonstances de l'époque.

D'abord, précisons que le texte en anglais est dû au fait que Bill a mis les pieds dans les plats. C'était en avril de 1992, quand j'étais professeur invité au Département de littérature comparée de l'Université de Montréal, alors qu'on m'avait invité pour donner une conférence, au Department of Germanic Languages and Literatures de l'université de Chicago sur les problèmes de la réunification allemande. L'idée d'expliquer à partir d'expériences vécues quelques phénomènes et tendances de ce qu'à l'époque on appelait les procédures d'une union inter-allemande des systèmes scientifiques et culturels (tendances qui par la suite se sont encore accentuées), était sortie des discussions que Bill animait durant le séminaire collectif de recherche qu'il dirigeait avec Jean-Claude Guédon pendant le trimestre d'hiver de 1992. Dans le cadre du thème de ce séminaire, les Etudes Culturelles et leurs institutions, Bill s'intéressait vivement à ce qui se passait en Allemagne. J'avais esquissé ma conférence dans un anglais plutôt "clumsy" que Bill m'aida à transformer en une version compréhensible. Je l'ai laissé tel quel, sans changer le caractère improvisé et la structure d'un texte fait pour être dit.

Sur les enjeux des problèmes que j'avais abordés, Bill et moi sommes revenus à plusieurs reprises lors de nos rencontres à Montréal, jusqu'au moment où il préparait 
son projet d'un long séjour d'études en Allemagne (surtout à Berlin) pour y étudier "The University as a Contemporary Institution of Knowledge". Le 7 octobre 1994, il m'envoya par télécopieur le "Research Plan" de ce projet que j'avais apprécié tant pour son approche que comme une heureuse chance de pouvoir poursuivre sur place et en personne nos discussions.

Je me permets de soumettre à l'attention des lecteurs de Surfaces certains passages du projet de Bill dans lesquels il situait la crise internationale de l'université en rapport avec la situation particulière de l'Allemagne:

How, then, is the University to be understood once the story of liberal education has lost its organizing center: the idea of culture as the object of the human sciences, both their origin and their telos? The process I have raced suggests that nostalgic appeals to Humboldtian ideals concerning the value of the humanities are likely to have little force in a world of shrinking powers of taxation, where national self-affirmation seems less central to human existence. The aim of my research is to look at the current reorganization of the German University in the light of the historical tradition that I have sketched in order to understand what is at stake in the institutionalisation of knowledge at the end of the twentieth century and to suggest ways in which the human sciences can continue to play a vital role in the structure of the University, even after the notion of national culture has ceased to serve as the guiding principle of the institution. (...)The particular situation of Germany is of special interest in that it is undergoing, simultaneously, both an internal and an external integration. Internally, the process of unification has required a specific attention to the restructuring of the University system in order to integrate the systems of the old Bundesrepublik and DDR. Externally, Germany's role within the European Union makes it a leader in the process by which the remaining vestiges of medieval corporation are being gradually removed so as to create an integrated European University system.

J'espère que tous les amis et collègues (étudiants et professeurs) que Bill savait intéresser par son projet reprendront ses idées, d'une façon ou d'une autre, pour 
contribuer à revitaliser l'espace universitaire - tant à l'intérieur qu'à l'extérieur des murs de l'institution.

Berlin, décembre 1995

\title{
Transforming Differences into "Normality" German Unification and the Crisis of the Humanities
}

\author{
"You can't discuss the difference between two \\ experiences." \\ (Ernst Jünger)
}

Two years after the German unification process which followed the unexpected end of the GDR, several provisional summaries speak of a failure (even of a disaster), of missed opportunities regarding a hoped-for unification of differing structures. In this sense, the inquiries into the differing experiences (at every level) of Germans in their 50-year history under separate political and economic regimes, seem to have failed. At the beginning of the unification process, both sides circulated, many ideas and well documented projects on procedures for the reform of institutional structures. Nowadays all these projects can be considered as "shattered illusions". The characterization of what has been called, curiously enough, a "non-violent revolution", as an "Umbruch" (a revision of galley proofs), to use a typographical term metaphorically, can now be seen as the delivery of a provisional historical text-event for correction according to demands of the so-called "train of history", so that it may receive the imprimatur of the "free will of the sovereign people". It was significant in this sense that one of the first acts after the fall of the Berlin wall was the closure of the Berlin Museum of German History on the grounds that the representation must be thought over and put into a new order!

The driving force of the printing-press (in every sense of pressure) that demanded a new text for correction, the force at the origin of unification, has become the "phantom" of the free market economy which has replaced the "Communist Specter" stalking Eastern Europe. 
The machinery of this printing-press is altering all areas of the people's economic, social, cultural, and political life in what now are the eastern parts of Germany, organized in the "Fünf Neue Länder", while in the former Federal Republic of Germany not one page in the text of history has been turned. The wall came tumbling down and the Germans came together, but only to be united unequally!

What makes it difficult (but nevertheless necessary) in a time of increasing tension and dramatic conflicts, to think about what has happened since German unification (and about its impact elsewhere) is the climate of ideological mystification, above all concerning the StasiAffairs, which have created a real psychosis in the country.

To give you an idea of the climate of feeling I quote from a report presented last January, by a psychotherapist from the Medical Academy of the city of Magdeburg, to an inter-german psychoanalytic conference. The author, Paul Franke, began with the observation that, psychologically speaking, unification occurred without the Germans being in any sense prepared for it, that is, it came as a shock:

As psychotherapists working in the GDR we achieved a relative autonomy from state doctrine. We employed depth psychology and psychoanalysis in our daily work in group therapy. This work was always regarded with suspicion from above. I find some analogies between the group dynamics and the interGerman situation since unification. After a short phase of warming up (as you know), the group found itself in a phase of dependence the therapist on whom they projected all sorts of expectations and illusions. In a very short phase of activation and independence the group overturned this sublimated role of the therapist. At this point the group gained its structure and identity. Only now the real work begins, when the group may work through (Durcharbeit) its problems.

All analogies are imperfect. But I would say that the phase of political unification can be compared to the dependency-phase. We observe expectations and illusions about unity, about the Deutschmark, about chancellor Kohl, dominating the thinking of the people. 
Currently we are entering the second phase, with the onset of disillusionment and of activation. Only after this phase will constructive work be possible. When we sit down together, we must nonetheless take up different positions. Real unification can begin only when we accept our differences without rushing to prejudiced conclusions. We haven't yet reached this phase. Up to now we have been mostly confronted by clichés. The "WESSI" are considered arrogant, loud, steamrollering, and holier-than-thou. The "OSSI" are supposed to be lazy, servile, selfpitying and self-flagellating.

The question I want to ask is, why did attempts at real reform of the universities and of academic institutions, at a necessary renewal of the whole academic landscape, end up in a cul-de-sac or dead end? Why was it possible for the ailing West German scientific and university system in the field of the humanities to be stuck onto the even more terminally ill Eastern system as its own mirorimage?

As for the humanities and from my personal point of view and experience in the former Institute of Literary History of the East Berlin Academy of Science, I want to give you some provisional answers. What I'm saying must be considered as observations from within (intra mures) about the humanities as an institutionalized discourse system lying within the borders of a rigidly organized and totalizing society. The inherent contradiction of this GDR-typical "Organisationsgesellschaft", a concept invented by Detlef Pollack, a historian of religion at the University of Leipzig. This notion reflects the wishful thinking of the rulers of the political and economic administation, who hoped to maintain corrupt power relations through certain forms of modernization, can briefly described as follows:

On the one hand in the GDR there occurred, as in highly industrialized societies, processes of differentiation between the spheres of economy, politics, science, jurisprudence, art and of religion, with the effect that these functional systems gained more and more specific dynamics and autonomy. Likewise, as in the Western industrial nations, we experienced increasing social conflicts because of the process of urbanization, mobilization, technologization, and rationalization in general. The euphoric politics that imposed 
scientific and technological progress resulted in serious ecological problems, in the field of military politics and in social and professional relations. All these subsequent problems caused a decrease in confidence among the people, and the loudly proclaimed prospects of science and technology (and those of political problems in general) lost their credibility.

On the other hand, we simultaneously had politically motivated processes of dedifferentiation which annihilated the autonomy of the different social spheres. Politics and ideological legitimation could intervene at every moment as the totalizing and allcontrolling instance.[ $\underline{\mathbf{1}}$ ]

Now any observer of the GDR as a political and social system (whose official description as "real socialist" blocked its further really socialist development) could note at a glance this tendency towards homogenization. The party (SED) considered itself the leading force in society and tried to impose its image of socialism on society as a whole. The construction of socialism in this way was the political objective which directed all its actions. In order to achieve the political objective of constructing socialism, they needed the collaboration of all other social forces, of industrial enterprises, of institutions, of other parties and of the citizens. But the party kept the command and control of this work of construction exclusively to itself. As a result, all specific social systems were subjected to the domination of the political and were very strongly limited in their autonomy and in their pursuit of system-specific goals. One could say that the party established a kind of osmosis between the different social systems and so established the whole society (in a holistic way) as its own organization.

Within this complex double-bind situation the humanities were integrated as a monolithic system of the so-called "Gesellschaftswissenschaften" (social sciences, though this is a Marxist usage which should not be confused with usual understanding of the social sciences). Originally this concept implied a critique of the alienation and escapism included in the German concept of "Geistesgeschichte" which had made the humanities incapable of resisting the ideological violence of Nazism. One could say that this Marxist concept was thought of as deconstruction of the German concept of "Geistesgeschichte" (which by the way was introduced into German in the mid-19th century as a translation of 
John Stuart Mill's "Moral Science"[ $\underline{\mathbf{2}}$ ]). This concept of "Geisteswissenschaften" was transformed further on when Marxism was institutionalized in the universities during the fifties as a "scientific world vision"

(Wissenschaftliche Weltanschauung) and was utilized in order to instrumentalize the humanities as "Herrschaftswissenschaften", as sciences for legitimization of the dominant power.

The abuse (even the erosion) of the critical force of Marxism, its transformation into a trivialized "grand récit", into an official discourse of representation whose idealized referent was the working class who itself had no voice, had serious consequences for the theoretical development and for modernization of Marxism itself. Marxism was represented officially by the sadly famous M.-L.-Sections (Abteilung für Marxismus-Leninismus) in the universities. The degradation of the concept of "Gesellschaftswissenschaften" in this way subordinated the different disciplines as parts of the super-system of the "Marxist-Leninist philosophy".

This reached the ludicrous extreme of excluding sociology and anthropology from the system of the "Gesellschaftswissenschaften" on the basis that historical materialism by itself deals perfectly well with the domains of these sciences. Philosophy was placed at the head of this hierarchical system as both the representative and the ruling instance of regulatory and prescriptive knowledge.

The desastrous consequences of this instrumentalization of the humanities are above all of two kinds.

First, instrumentalization gave rise to a sort of aversion for theory in general and for modern Marxist thinking in particular among researchers and intellectuals in the humanities. Second it favored a certain intellectual isolation and defensiveness and a strong trend toward empirism without a theoretical frame, accompanied by a refusal to intervene in actual problems. The retreat to areas of past history was considered a way to avoid political engagement. And the loss of critical-theoretical thinking opened the door to a somewhat historicist concept of history, for what Walter Benjamin called "the empty linear time of history".

Imaginary walls arose between the different disciplines, and the intellectuals lived and worked with a certain "bunker-mentality". It is significant, for example, that departments of comparative literature never existed in the GDR-universities, because comparatism was 
considered by those in power to be dangerous cosmopolitic work that might undermine the principles and dogmas of what was considered to be Marxist aesthetics.

Thus the creation of ideologically motivated frontiers, both between different disciplines of the humanities and around the humanities in general, to protect against the international developments, took place in the name of an "Auseinandersetzung", a polemic critique of bourgeois ideology. (Auseinandersetzung was a specific form of polemic criticism which always involved asserting the sole truth of Marxism while changing its position according to political circumstances). These frontiers encircled a theoretical vacuum in the humanities which was filled after unification by a melting pot of so-called "Western standards". The humanities became integrated in, to the West German system of research and teaching, resulting in domination by the "discourse of normality".

The language of the humanities has changed since unification. The concept of

"Gesellschaftswissenschaften" has been replaced by that of "Geistes- und Sozialwissenschaften" and Marxism has given way to hermeneutics.

Thus, for example, in the course descriptions which our new West German masters have required us to prepare, old courses have been retitled. "Marxist interpretation of the French Novel" has been replaced by a kindler, gentler, "hermeneutic interpretation of the French Novel". Perhaps we can no longer pretend to be shocked at this absence of critical reflection in the universities.

\section{The use of national(istic) markers in the discourse on the humanities}

Unification led to the elimination of the instutionalized enemy-images between the two Germany's, which found their classical expression in the use of culture (and also science) for the legitimation of political regimes. Remember the neverending discourse on the German unity as a Kulturnation, which was one of the main ideologemes in the West, critized in the official discourse in the East with the Leninist argument that in every nation there exist at least two different and opposing cultures. Now the division-line had to be defined otherwise. The unified political space had to be also the space of a German culture, excluding all forms which 
could be considered as projecting a sort of "subjunctive culture".

In this sense I would say that "unification" in the field of the humanities was realized in the form of a huge "totalization". This can be characterized as a transformation of differences and otherness into "normality". I use the definition given by Georges Canguilhem who wrote in his essays on "The Normal and the Pathological":

Normer, normaliser, c'est imposer une exigence à une existence, à un donné, dont la variété, la disparate s'offrent, au regard de l'exigence, comme un indéterminé hostile plus encore qu'étranger. Concept polémique, en effet, que celui qui qualifie négativement le secteur du donné qui ne rentre pas dans son extension, alors qu'il relève de sa compréhension.

The discourse on normality called for a reformulation of the confrontation between different systems or blocs which existed since the Cold War Period in the "normality" of mutual "Bedrohung" (threat) and "Gleichgewicht" (Balance of Power). The task (in the case of German unification) being the adaptation (Angleichung) of one system to another, that is to say of the East-German to the West-German. It has been highly significant that during this process, which became politically justified with the decision to procede to unification by order of article 23 of the West-German constitution (the Grundgesetz), value notions (or categories) were put forward without taking into consideration their critical questioning-a questioning under way for several years in conjunction with the fundamental crisis of the humanities and of the universities in the western parts of Germany.

Among those value notions are "Enlightenment", "Humanism" and "Bildung" which were used as criteria and measures in order to reform the East-German system of education and research. This discoursemachine worked very well because the arguments referred generally to the political and ideological instrumentalization of culture and science in the GDR and overlooked the important differences (be it by ignorance or by the will to qualify the whole Eastern educational system as a mere "desert," as declared in 1990 by the former president of the Max-Planck-Society). 
I would like to characterize this normalizing discourse which is orientated "extra muros" by naming just three distinct examples which may illustrate it as a projection on to the "other" Germans of inner crisis and problems.

1. It was Ulrich Greiner, a critique who re-coined the term "Gesinnungsästhetik" (aesthetics of conviction) in his opening-article of the Christa-Wolf-Debate[ $\underline{\mathbf{3}}$ ], who made the generalizing statement that attempts to normalize the German historical situation "is no academic question. Whoever determines what was also determines what will be!" This is a formulation marked by an affinity to Carl Schmitt's definition of the sovereign as he who determines the "State of Emergency"

(Ausnahmezustand). One could say (recalling an analysis made by Andreas Huyssen) that the "normalization" of East German culture according to "Western standards" became something like a second historian's debate:

The inmediate purpose is not the normalization and exculpation of Nazi-Germany as it was in the earlier debate, the Historikerstreit. But at issue again is a selective and self-serving apportioning of guilt, as well as the erasure of the past, this time that of the predominant culture of the two German States from 1949 to the present. The purpose of this discourse is closure: an Abwicklung (wrapping up)-to use a term recently invented for the closing of whole faculties at East German universities.[ $\underline{4}$ ]

2. Another (more specific example concerning our work as literary critics) is given by a sort of intellectual protectionism by using curious and at first glance even ridiculous national (or nationalist) markers in the theoretical debate. Thus the use of hermeneutics as "the only great exportation in the field of German humanities" (F. Tenbruck). As institutionalized Marxism had a strong tendency to occupy the truth and horizon of the future, the hermeneutic pluralism of sense-building had good press after unification. But, once again, it seems to me that we are confronted with a sort of critical blindness and that critical insight as its counterpart will be a task for the coming years.

3. The third example refers to Jürgen Habermas and his reflection about what he called the "belated revolution" (Nachholende Revolution[ $\underline{\mathbf{5}}$ ]). Habermas took a position regarding what he called the "belated revolution" in the 
GDR that didn't find anything new in it. There was "no new light thrown on our old problems". What was going on seemed to be nothing other than the confirmation of "negative invariants" in the increasing speed of history. His text, written just before the elections to the Peoples Chamber in March 18 (1990), is a significant document for its simultaneous disillusionment and self-confidence. As such it marks the blindness of his concept of Aufklärung and modernity, which remains the everlasting ideal and utopia and which makes it impossible to understand the historical events in Eastern Europe (and elsewhere) as the definitive twilight of modernity. What is striking in Habermas' philosophical analysis of the events of the GDR'S belated revolution is the circular figure of revolution understood in pre-1789 terms as an orbital merry-go-round movement. "Rarely has the jubilation of a revolution been silenced so quickly as in Germany after the November 9th, 1989."

Habermas's logic of salvation (Logik der Rettung) is blind to the moments of catastrophic normality which we are living in and to the very obvious signs that, after the fall of the Berlin wall, the Aufklärung-fiction of a universal Tower of Babel in the name of reason can never be rebuilt.

The end of bureaucratic state socialism appears to him as another example of the vitality (Lebendigkeit) of modernity, "as the victory of the Occident over the Orient, not only by the force of its technical civilization but also by its democratic tradition. The impact of modernization has reached Middle and Eastern Europe" (185).

Regarding the prospects and the task of the "noncommunist left", they remain the same ones that Habermas always prescribed. The non-communist left must organize the "radical reformist autocritique" of capitalist society as representatives and watchmen of the "hope of the people's emancipation". He also advises the intellectuals of the former GDR to join in this learning process, changing their place and their role in order to take part in the glorious and endless rotation of modernization. (203)

\section{The frame of institutionalized discourse systems}

The desire for cultural and scientific legitimation explains the importance given by the ancient regime to 
culture in general. Cultural criticism and cultural history in the humanities should establish the frames of understanding and interpretation. There was a sort of fear on the part of the political power that neglecting culture might make evident economic weakness-culture being considered as proof (or as illusion) of a well working economy. What our West German collegues have failed to understand, is that the official desire to totalize the cultural spheres produced important effects of resistance and of critical alterity.

For example, in aesthetics and art criticism the discourse system of realism and socialist realism which following certain prescriptions of the theories of G. Lukács, dominated in the universities (as elsewhere too) has become increasingly eroded since the 60 s when the socalled Brecht-Lukács-Debate opened a new and different field of aesthetic thinking.

Or, to give you another example, in philosophy the discourse system had been dominated by the very Manichaean idea that modern philosophy since the Enlightenment (and above all in Germany) should be understood as a big battleground between rationalism and irrationalism, following once again the prescriptions of Lukacs's book "Destruction of Reason" (Die Zerstörung der Vernunft, 1954).

One of the consequences of such black-and-white thinking was for example the discrimination against romanticism. Since the 70s, however, we can observe the dissolution of this discourse. This change was due to critiques advanced by humanist poets and scholars were jointly rethinking romanticism.

For the time being, the crisis of the humanities which became once more explicit after German unification, has left us with the pressing task of developping a thought that is not situated within this crisis which is now nearly 200 years old, but rather outside its margins.

Opposing the unifying and authoritarian discourse of "normality", we must consciously accept the conflicts, differences and paradoxes of our situation rather than seeking (in the bad old Hegelian manner) to universalize and to reconcile them (versöhnen). By saying adieu to all kinds of representative functions, we can develop in every field of our activities new forms of analysis and of resistance (in the sense Jean-François Lyotard gives to this concept). And we may keep in mind the warning given once by Heiner Müller: 
The spiral of History destroys the center, breaking through from the marginal zones. In this process, which cannot be grasped from the viewpoint of a single generation, progress is thrown into doubt. This doubt is existential, insofar as humanity has not developed any new consciousness of itself as a species. Any new Universal History would presuppose the development of such a consciousness of humanity as a species. The loss of consciousness of the human species was the price that humanity had to pay in order to distinguish itself from the animal kingdom. The way back to the animal kingdom is merely a romance of primitivism, while the modern attempt to transform the spiral of history into a circle will result in the plant's destruction.[ $\underline{\mathbf{6}}$ ]

The recent trend which proposes a new concept of culture, rethinking its domains and its theoretical frames, leads to a productive challenge to criticism and methods in the humanities and destabilizes the traditional borderlines of their disciplines. The historical constitution of the humanities in Europe (and above all in their German tradition as Geisteswissenschaften) since the founding of our disciplines in the 19th century, has exacted the price of a separation of objects, of fields, and of disciplines from each other, so that we are still confronted by what Benjamin has called the "territorialization of culture and the arts". A further result of this specific division of intellectual and scientific labor (without regard to the different national forms it has taken), has been an "amazingly rigid structure" (E.W. Said) in its institutionalization. This disciplinary (and disciplining) specialization made us aware of the necessity to think (and to rethink) the complexities, because (and above all) it has been "one depoliticising strain of considerable force, since it is capitalized on by professions, institutions, discourses and a massively reinforced consistency of specialized fields. "'I'm sorry I can't understand this-I'm a literary critic, not a sociologist etc.'"[ 7 ]

Marxist criticism, which has been at its best constituted by a constellation of excellent thinkers, has however also been deeply affected by this specialization, in particular since its official institutionalization in the now defunct socialist societies. This is a very complicated story and a history which is only at the beginning of a deeper deconstruction. One of the main problems is the curious 
absense of reflection on the problem of the media in the writings of classical Marxism, whereas in certain traditions of utopian socialism and of anarchism (for example in the writings of Charles Fourier) we may find an awareness of these problems. It is perhaps this sort of blindness to the modern media that lies at the root of a certain affinity between old-fashioned Marxism and hermeneutics.

Another sort of black-box which has been remembered by Walter Benjamin is the forgotten and hidden problematic of an anthropological materialism. The history of such anthropological materialism is directly related to utopian socialism, particulary in France. In Germany it is linked to the critique of religion developed by Feuerbach. The leading idea of "human emancipation" in the early writings of Karl Marx is important as a starting point in the elaboration of the concept of historical materialism. However, the Marxian Aufhebung of this anthropological materialism on the road to what Engels later on called the necessary shift from utopian to scientific socialism, contributed to the disappearance of (and even the discrimination against) this tradition in further Marxist thinking. Although Marx never ceased stressing the revolutionary importance of Fourier's philosophy of the sensual and of desire, his utopia of a society free from the division of labor, this "Warm Stream" of materialist thinking (to use a distinction made by Ernst Bloch between Warmstream and Coldstream in materialist thinking[ $\underline{\mathbf{8}}]$ ) has been subordinated and even fought in the name of rationality in all socialist societies. What Marx celebrated as a specific outcome of the French Enlightenment and as an important alternative to the actus purus of German idealism was thrown into oblivion.

Remembering the motto which I choose for this lecture, that "you can't discuss the difference between two experiences", I conclude with a remark made by Walter Benjamin in his essay on "Literary History and Literary Scholarship", a remark whose prospective horizon can be situated beyond any apocalyptic or nostalgic vision of history:

It is not a question of presenting written works in the context of their time, but of bringing forth the time which recognizes them-that is our time-within the time that produced them. With that, literature becomes an organon of history (Geschichte) and not material for historiography (Historie), the task of literary history is to make it so. 
(Translation by Delphine Bechtel).

\section{NOTES}

1. Detlef Pollack, "Das Ende einer

Organisationsgesellschaft. Systemtheoretische

Überlegungen zum gesellschaftlichen Umbruch in der DDR." Zeitschrift für Soziologie (Stuttgart), vol. 19, No. 4 (August 1990), 292-307.

2. Cf. Wolfgang Frühwald/Hans Robert Jauss/Reinhart Koselleck/Jürgen MIttelstrass/Burkhart Steinwachs (Eds.), Geisteswissenschaften heute. Eine Denkschrift (Frankfurt 1991).

3. Ulrich Greiner, "Die deutsche Gesinnungsästhetik". In Thomas Anz (Ed.), Der Literaturstreit im vereinten Deutschland, München, 1991, 208-216.

4. Andreas Huyssen, [référence manquante].

$\underline{\mathbf{5}}$. Jürgen Habermas, Die nachholende Revolution. Kleine Politische Schriften VII, Frankfurt, 1990, 179-204.

6. Ein Gespräch zwischen Wolfgang Heise und Heiner Müller. In W. Heise (Ed.), Brecht 88. Anregungen zum Dialog über die Vernunft am Jahrtausendende, Berlin, 1987, 189.

7. E. W. Said, "Permission to Narrate". In London Review of Books (16-29 Feb. 1984).

8. Cf. Ernst Bloch, Das Prinzip Hoffnung, vol. 1, Berlin, 1954, 213-242.

Accueil Surfaces | Table des matières | Recherche Surfaces Home Page | Table of Contents | Search

PUM | Livres | Revues | Publications électroniques | Vente et distribution 